\title{
First report of Lymnaea cousini Jousseaume, 1887 naturally infected with Fasciola hepatica (Linnaeus, 1758) (Trematoda: Digenea) in Machachi, Ecuador
}

\author{
Ángel Villavicencio $\mathrm{A} /{ }^{+}$, Mauricio Carvalho de Vasconcellos ${ }^{*}$
}

Department of Veterinary Pathology, Agrary Faculty, Russian People's Friendship University, Moscow-Russia, 117-198, St. M. Maklaya 6 *Núcleo de Biologia e Controle de Endo e Ectoparasitas de Interesse Médico e Veterinário, Departamento de Biologia, Instituto Oswaldo Cruz-Fiocruz, Rio de Janeiro, RJ, Brasil

We report the first finding of Lymnaea cousini naturally infected with Fasciola hepatica in Ecuador. A sample of 70 snails was collected in April 2005 from a wetland located in a valley at approximately $3000 \mathrm{~m}$ a.s.l., near the locality of Machachi, Pichincha Province. The prevalence of natural infection in L. cousini was $31.43 \%$, which is the highest value ever recorded for naturally infected lymnaeid species.

Key words: Lymnaea cousini - Fasciola hepatica - Ecuador

Fascioliasis, one of the main diseases of ruminants, is caused by the liver fluke Fasciola hepatica. This worldwide distributed disease occasionally affects humans and produces an important economic impact on livestock due to reduced weight gain, lowered fertility and abortion, progressive decrease in milk yield, as well as liver condemnation. The annual losses to the agricultural sector are estimated to be US\$2.2 million, with over 600 million animals infected worldwide (Dalton 1999).

In Ecuador the present prevalence of $F$. hepatica in livestock remains uncertain because most data are collected by sanitary inspectors from slaughter houses. The Andean region is the endemic area of fascioliasis, where prevalence of infection in livestock ranges from 20 to $60 \%$ and in humans from 24 to $53 \%$ (SESA 2003). This region is inhabited by 23.6 and $52.9 \%$ of the total and rural population, respectively; almost 200,000 people are infected and $1 \%$ are at risk of infection (WHO 1995).

Despite fascioliasis being a serious health problem in the country, very little is known about snails of the genus Lymnaea, the intermediate hosts responsible for $F$. hepatica transmission.

Some of the lymnaeid species occurring in Andean countries are as follows: L. truncatula Müller, 1774 from Bolivian highlands (Jabbour-Zahab et al.1997, Mas-Coma et al. 1999) and Venezuela (Pérez Mata 2003); L. columella Say, 1817 from Venezuela and Ecuador (Pérez Mata 2003); L. cubensis Peiffer, 1839 from Venezuela (Pérez Mata 2003) and L. cousini Jousseaume, 1887 (syn. L. ubaquensis

Financial support: Fundacyt, Proj. 2005701

+Corresponding author. Email: fveterinario@hotmail.com Received 22 July 2005

Accepted 7 November 2005
Piaget, 1912; L. bogotensis Pilsbry, 1935; see Hubendick 1951 and Pointier et al. 2004). L. cousini has been found in Ecuador (Jousseaume 1887, Paraense 1995, 2004), Colombia (Piaget 1912, Pilsbry 1935), and Venezuela (Pointier at al. 2004), but no report concerning natural infection has ever been published.

The aim of this study is to report the first finding of $L$. cousini naturally infected with $F$. hepatica in Ecuador.

A sample of 70 snails was collected in April 2005 within a private farm where fascioliasis in cattle was previously diagnosed by faecal examination. It was located near Machachi (78 $30^{\circ} \mathrm{W}, 00^{\circ} 30^{\prime}$ S, $3100 \mathrm{~m}$ a.s.l.) in the Pichincha Province. The sampling site was a wetland placed in a relatively low valley at approximately $3000 \mathrm{~m}$ a.s.1. and covered an area of $4.5 \mathrm{~m}^{2}$. Water in the wetland flowed slowly, had a maximum height of $10 \mathrm{~cm}$ and $\mathrm{pH}$ was 6.5 . The soil is volcanic in origin, and vegetation was composed of Ray-grass (Lolium sp.) and aquatic plants.

Snails collected were kept alive in plastic containers with wet cotton pads and transported to the Department of Malacology of the Instituto Oswaldo Cruz, Rio de Janeiro, Brazil. Upon arrival at the laboratory, ten specimens were relaxed, killed, and preserved according to Paraense (1984), and their taxonomic identification was performed by Dr Paraense on the basis of features of the shell and internal organs (Paraense 1995). The remaining snails shared the same external appearance as those already determined. Specimens were examined for the presence of larval stages of $F$. hepatica under stereoscopic microscope.

All 70 collected snails belonged to L. cousini Jousseaume, 1887 (Figs 1, 2), and $22(31.43 \%)$ were infected with F. hepatica (Fig. 3).

Shells of L. cousini specimens from Ecuador described by Jousseaume (1887) ranged 10-14 $\mathrm{mm}$ in height and 6-10 $\mathrm{mm}$ in diameter with an aperture of 7-10 $\mathrm{mm}$ long, while those from Venezuela varied 6.6-9.3 $\mathrm{mm}$ in height and 3.7$6 \mathrm{~mm}$ in width (Pointier et al. 2004). 
The surprisingly high prevalence of natural infection with $F$. hepatica in $L$. cousini may be explained by environmental conditions favouring the development of snail populations and the transmission of the parasite. Valleys in the Andean region of Ecuador are characterized by tem-

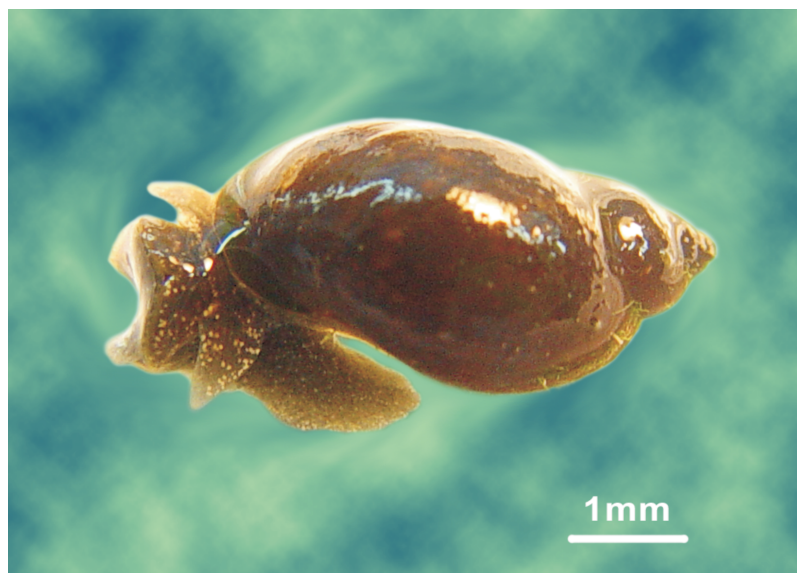

Fig. 1: Lymnaea cousini from Machachi, Ecuador.

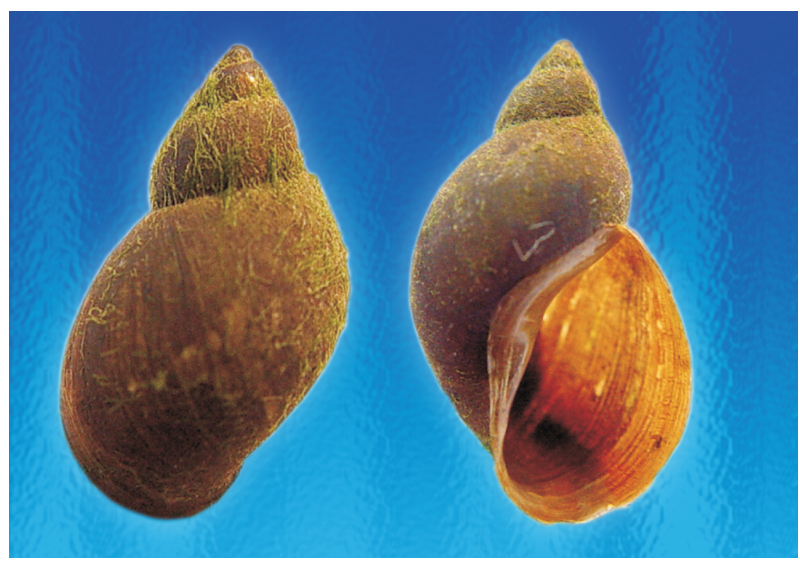

Fig. 2: shells of Lymnaea cousini collected in Machachi, Ecuador.

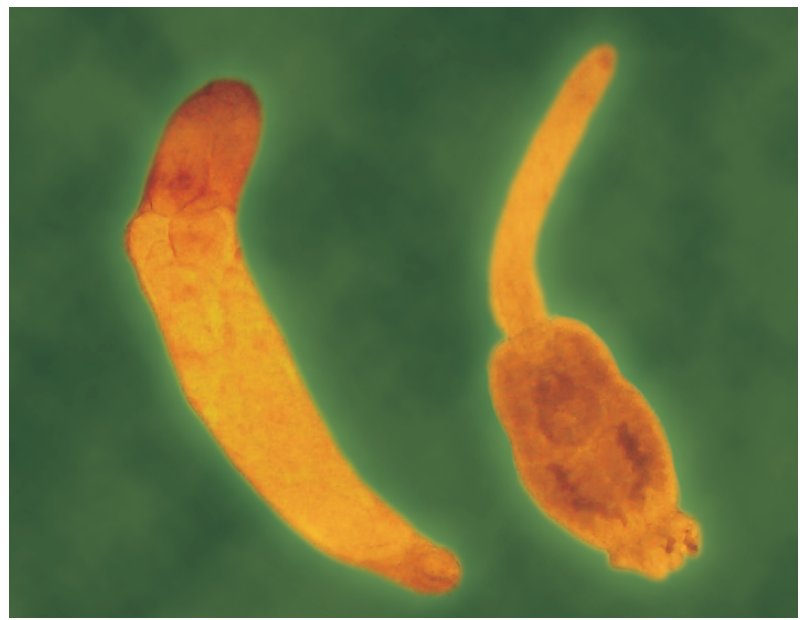

Fig. 3: redia and cercaria of Fasciola hepatica in naturally infected Lymnaea cousini from Machachi, Ecuador. 50× peratures ranging from 10 to $30^{\circ} \mathrm{C}$, frequent precipitation, numerous streams, and low-permeable soil layers. In addition, anthropogenic factors involving irrigation of pasture lands by flood or ditches and inappropriate management of grazing cattle are unlikely to prevent infection in both intermediate and definite hosts.

The prevalence of $F$. hepatica in $L$. cousini from Machachi, Ecuador (31.43\%), is the highest value ever reported for lymnaeid snails naturally infected with this parasite. In Brazil, L. columella showed the following infection rates: $2.4 \%$ in Rio de Janeiro (Rezende et al. 1973); 5.2 and 3.9\% in Minas Gerais (Coelho \& Lima 2003); 1.22 and $0.14 \%$ (Ueta 1980), 5.26\% (Oliveira et al. 2002) in São Paulo; $3.3 \%$ in Rio Grande do Sul (Silva Santos et al. 1987). In Corrientes, Argentina, the prevalence of L. columella was $8.8 \%$ (Prepelitchi et al. 2003). In central France, Rondelaud et al. (2001) reported a global prevalence of natural infection of $1.1 \%$ in L. truncatula and $0.3 \%$ in $L$. glabra. In the Russian Federation, L. truncatula populations showed infection prevalences ranging from 0.05 to $0.72 \%$ (Villavicencio 2004).

\section{ACKNOWLEDGEMENTS}

To Dr Wladimir Lobato Paraense, Department of Malacology, Instituto Oswaldo Cruz-Fiocruz, for his valuable help in identifying the snails. To Natalia Dondua for field assistance. To AF Barbosa for the photographs, and to all the people who lent their support and assistance during this study.

\section{REFERENCES}

Coelho LHL, Lima WS 2003. Population dynamics of Lymnaea columella and its natural infection by Fasciola hepatica in the state of Minas Gerais, Brazil. J Helminthol 77: 7-10.

Dalton JP 1999. Fasciolosis, CABI publishing, New York, $562 \mathrm{pp}$.

Hubendick B 1951. Recent Lymnaeidae. Their variation, morphology, taxonomy, nomenclature, and distribution. Kungl Svenska Vetenskapsakad Handl (4 ser) 3: 1-223.

Jabbour-Zahab R, Pointier JP, Jourdane J, Jarne P, Oviedo JA, Bargues MD, Mas-Coma S, Anglés R, Perera G, Balzan C, Khallayoune K, Renaud F 1997. Phylogeography and genetic divergence of some Lymnaeid snails, intermediate hosts of human and animal fascioliasis with special reference to lymnaeids from the Bolivian Altiplano. Acta Trop 64: 191203.

Jousseaume F 1887. Mollusques nouveaux de la République de l'Equateur. Bull Soc Zool France 12: 165-186.

Mas-Coma S, Anglés R, Esteban JG, Bargues MD, Buchon P, Franken M, Strauss W 1999. The Northern Bolivian Altiplano: a region highly endemic for human fascioliasis. Trop Med Int Hlth 4: 454-467.

Oliveira SM, Fujii TU, Sposito Filha E, Martins A 2002. Ocorrência de Lymnaea columella Say, 1817 infectada naturalmente por Fasciola hepatica (Linnaeus, 1758), no Vale do Ribeira, São Paulo, Brasil. Arq Inst Biológico 69: 29-37.

Paraense WL 1984. Lymnaea diaphana: a study of topotypic specimens (Pulmonata: Lymnaeidae). Mem Inst Oswaldo Cruz 79: 75-81. 
Paraense WL 1995. Lymnaea cousini Jousseaume, 1887, from Ecuador (Gastropoda: Lymnaeidae). Mem Inst Oswaldo Cruz 90: 605-609.

Paraense WL 2004. Planorbidae, Lymnaeidae and Physidae of Ecuador (Mollusca: Basommatophora). Mem Inst Oswaldo Cruz, 99: 357-362.

Pérez Mata AM 2003. Contribuciones a la Caracterización de la Fascioliasis en Países Andinos, Transmisión, Parásitos $y$ Vectores en Venezuela, Perú y Ecuador. PhD Thesis, Facultad de Farmacia, Universidad de Valencia, España, $544 \mathrm{pp}$.

Piaget J 1912. Quelques mollusques de Colombie. Mém Soc Neuchatel Sci Nat 5: 265-269.

Pislbry HA 1935. South American land and freshwater molluscs, IX-Colombian species. Proc Acad Nat Sci Philadelphia 87: 83-88.

Pointier JP, Noya O, Amarista M, Théron A 2004. Lymnaea cousini Jousseaume, 1887 (Gastropoda: Lymnaeidae): first record for Venezuela. Mem Inst Oswaldo Cruz 99: 567-569.

Prepelitchi L, Florencia Kleiman, Silvia M Pietrokovsky, Ricardo A Moriena, Oscar Racioppi, José Alvarez, Cristina Wisnivesky-Colli 2003. First report of Lymnaea columella Say, 1817 (Pulmonata: Lymnaeidae) naturally infected with Fasciola hepatica (Linnaeus, 1758) (Trematoda: Digenea) in Argentina. Mem Inst Oswaldo Cruz 98: 889-891.

Rezende HEB, Araújo JL, Gomes PAC, Nurenberg S, Neto MP,
Oliveira GP, Mello RP 1973. Notas sobre duas espécies de Lymnaea Lamark, 1799, hospedeiros intermediários de Fasciola hepatica L. no estado do Rio de Janeiro (Mollusca, Gastropoda, Basommatophora, Lymmaeidae). Arq Univ Fed Rural 3: 21-23.

Rondelaud D, Vignoles P, Abrous M, Dreyfuss G 2001. The definitive and intermediate hosts of Fasciola hepatica in the natural watercress beds in central France. Parasitol Res 87: 475-478.

Silva Santos S, Laranja RJ, Costa NC, Bothelo GA, Ceresér VH, Martins JR 1987. Lymnaea columella Say, 1817 interagindo na disseminação de fasciolose na Estação Experimental Zootécnica de Dom Pedrito, RS. Hora Veterinária 6: 42-48.

SESA - Servicio Ecuatoriano de Sanidad Animal 2003. Estadísticas Anales de Control Epidemiológico, Quito, 90 pp.

Ueta MT 1980, Ocorrência de infecção natural de Fasciola hepatica Linnaeus, 1758 em Lymnaea columella Say, 1817 no Vale do Paraíba, SP, Brasil. Rev Saúde Pública 14: 230-233.

Villavicencio A 2004. Infección natural de moluscos L. truncatula con estados larvarios de Fasciola hepatica en regiones de Moscú. Material Conf Cient sobre la Lucha contra las Zoonosis 5: 199-122.

WHO-World Health Organization 1995. Control of foodborne trematode infections. Report of a WHO Expert Committee. WHO Technical Report Series, Geneva No. 84, 200 pp. 